\title{
Comprehensive Utilization and Development Trend of Corn Straw
}

\author{
Mingfen $\mathrm{Niu}^{1, \mathrm{a}}$, Huan $\mathrm{Liu}^{1, \mathrm{~b}}$, Mingmei Zhao ${ }^{1, \mathrm{c}}$ and Wenjuan Liang ${ }^{1, \mathrm{~d}}$ \\ ${ }^{1}$ School of Shenyang Jianzhu University, Liaoning 110168, China \\ a836580304@qq.com b619343522@qq.com 'c1158517006@qq.com
}

Keywords: Corn straw, Straw returning, Feed, Biological carbon.

\begin{abstract}
China's corn straw resources are very rich, the development of corn straw application technology industry has become a hot spot. In this paper, the present situation of comprehensive utilization of corn straw in China is summarized, including the utilization of corn straw as fertilizer, feed, raw material, fuel and straw carbonization. And analyzed the existing problems and development trend of corn straw utilization in order to provide a reference for the comprehensive development and utilization of corn straw in China.
\end{abstract}

\section{Introduction}

The rapid development of China's agriculture, the amount of crop straw resources is increasing. A survey shows that in 2010 the amount of straw resources reached 8.4 tons, of which the straw corn as the third largest crop in China, the annual yield is about 2.7 tons. In the corn straw resources utilization, with the straw returning to field, feed and fuel, the average of the study area was $30.8 \%$, $26.2 \%$ and $24.6 \%$., respectively, the total yield is less $1 / 3$. Most of the corn straw not only is decayed in the fields, but is directly in the burn ,which is a waste of energy and pollution of the environment.[1].In recent years, China attaches great importance to the issue of straw utilization, and strive to 2015 comprehensive utilization of straw reached $80 \%$ or more. Therefore, it is very important to promote the comprehensive utilization of corn straw, to make up for the deficiency of our country energy and to promote the sustainable development of agriculture.

\section{The application of corn straw in China}

At present, the use of corn straw has formed a diversified pattern. Corn stalks from the past only used as rural energy and livestock feed, extended to the use of fertilizers, feed, edible fungus, industrial raw materials, etc ;From the past traditional agriculture to modern industry energy field; from farmers in poor combustion to straw direct fired for power generation, straw biogas, straw curing, straw carbonization of efficient use; With the rapid development of the straw industrialization, straw man-made board, straw wood and other high value-added products also achieved industrial production.

\section{Corn straw fertilizer utilization.}

\section{a) Corn straw returning}

Corn straw as a renewable resource, containing nitrogen content is $0.6 \%$, phosphorus content is $0.27 \%$, potassium content is $2.28 \%$, organic matter content up $15 \%$ [2]. The corn straw returning can effectively improve the content of organic matter, enhance the soil fertility, improve the physical and chemical properties of the soil.

Corn straw returning mainly includes the agricultural straw are directly returned after stubble crushing, crop absorb the straw mineral composition by decomposition producing and it can promote the growth and improve of the yield. Because crop stalks for a long period of time to decay[3], the straw directly to the field will not be able to make full and direct contact with the soil, affecting the seed germination rate, hindering the growth of crop species[4].

Corn straw also includes returning indirectly,which is to add other nutrients after making corn straw fermentation. Including simple compost, wet compost and livestock manure fertilizer etc. Wet compost return refers to the cellulase produced by composting agent in a relatively short period of time, through the action of the enzyme to make crop straw composted organic fertilizer. Finally to 
achieve the purpose of organic decomposition, and to enhance the soil fertility .Thus providing an effective growth environment for the growth of crops[5]. Livestock manure fertilizer is the crop straw as forage, through digestion of livestock and applied into the soil by formation of manure, it is fertility, no side effects and the most ecological [6].

\section{b) The problems of corn straw returning to field}

(1)The amount of corn straw returning should be applied to $4500 \sim 6000 \mathrm{~kg} / \mathrm{hm}^{2}$ [7], Do not increase the amount of straw returning to the field, otherwise it will be detrimental to the growth of crops.

(2)Corn straw increased the fresh organic matter for the soil, and provided the living substrate for microorganisms. But the carbon nitrogen ratio is too large. Mineral $\mathrm{N}$ was needed in the process of microbial decomposition of straw, So the corn stalk returning to the field with the application of a certain amount of nitrogen fertilizer, regulating soil microbial carbon and nitrogen ratio.

(3)Microbial pathogens and parasite eggs adhered to crop stalks and were planted in soil after breeding and spreading[8]. Finally leading the spread of pests and diseases. So sick of straw (such as a corn leaf blight, northern leaf blight,) can not be directly returning.

\section{Corn straw feed utilization.}

Corn straw are rich in nutrients, the nutritional value of 4 tons of straw is equivalent to 1 tons of grain .Using the straw production technology to convert it into protein feed can reduce the cost, improve the economic benefits of aquaculture ,and open up a new path for efficient grain saving, resource oriented animal husbandry.

Straw feed processing mode is mainly changing the crop straw into high quality feed by the crushing, silage, microbial silage, ammoniation, particles etc, Silage and microbial silage are the most widely used methods [9].

Silage can maximize the preservation of the nutrient in the feed, the general loss of feed raw materials 3\%-10\%, and air dry feed can lose 30\%-50\% of nutrients, almost all of the loss of raw materials in vitamin[10]. Silage making simple low cost, feeding is not affected by seasonal and climatic constraints, ensuring year-round balanced supply of livestock. After ammoniated straw has soft texture, the nutrition is improvement. But plenty of data show that, there are many disadvantages of ammoniated feed: (1) the long-term use of ammoniated feed, total ammonia concentration 15\%-28\%, the case of Mars caused explosion. (2) the source of ammonia dosage is too large, when feeding is easy to cause ammonia poisoning in animals, so in front of the feeding should fully making the NH3 volatilization by airing .

Micro silage indicates that adding microbial activitive bacteria in the corn straw, and placed in a container or ground to ferment, after a certain process, corn straw transformed into wet expansion feed that livestock loving eating. Studies have indicated that the nutritional value of all kinds of crops after the micro silage treatment is significantly improved : Moisture content increased from 4\% to $10.2 \%$; crude protein was significantly increased from $8 \% \sim 30 \%$; crude fat increased $7 \% \sim 18 \%$; crude fiber decreased $20 \% \sim 30 \%$. Corn straw after micro silage compared with ammoniated straw, the crude protein content is lower than ammoniated straw, But the operation of the feed intake and daily weight gain were higher than that of ammoniated straw, lower cost than ammoniated. Of course, there is a large area of land to work and the inconvenience of transport.

Xie Tao[11] indicates the corn straw stalk is separated from the corn straw, according to the different breeding add some additives, after granulating of pellet feed become corn straw stalk pellet feed. Corn straw stalk pellet feed processing routes: corn stalk pith separation-corn straw stalk crushing — mixing — granulating drying — packaging. Due to the process of friction produces heat, the internal curing degree unrivaled, solidification of protein denaturation, in order to improve the digestion and absorption of nutrients, This way can kill the pathogenic microorganisms and bacteria, long storage without mildew, feed grain surface after processing and moderate hardness.

\section{Corn straw based material utilization (cultivated edible mushrooms).}

The organic components of corn stalk were mainly cellulose, hemicellulose, and lignin, protein and amino acids, so as the main raw materials of cultivating edible mushrooms. At present, the varieties of cultivated edible mushrooms with corn straw includes Agaricus bisporus , Coprinus 
comatus, etc. Using corn straw as the base material can reduce the production cost, and the end of the production of fresh mushrooms can be used as organic fertilizer directly into the field.

XiuHong Hua [12] provided for two related aspects of cultivation of edible fungi and livestock feed source to research straw 's degradation and transformation. The results showed that the majority of crop straw can be used as edible fungus production base. And formed "animal dung (straw feed application) — resources - crop — renewable resources (straw) - renewable products (edible mushrooms)—renewable resources (mushroom residue) — recycled products (herbivores) - renewable resources (dung)" cycle of agricultural eco industrial chain. Material in the circulation system can produce economic benefits, and energy-saving emission reduction also produce environmental benefits, In the process of the cultivation of edible mushroom and animal husbandry obtain a win-win situation, improving the comprehensive utilization of agricultural straw.

Cultivated edible mushrooms is good for promoting the agricultural ecological balance, promoting the transformation and upgrading of agriculture, changing the way of agricultural development, and accelerating the construction of modern agriculture with high efficiency. China should focus on the promotion of enterprises and farmers' business model, and actively build a batch of straw mushroom production base.

\section{Corn straw material utilization.}

Corn straw fiber is a kind of natural cellulose fiber with good biodegradability. It can replace wood in papermaking, the production of sheet metal, crafts, also can replace food in the production of xylitol etc.

Corn stalk rind cellulose content is about $44.6 \%$, higher than that of rice straw and wheat straw, which can be greatly improve paper strength [13]. With the continuous improvement of the paper technology of corn straw and the large area of application, the consumption of wood will be reduced, and the traditional paper production method of wood pulp, straw and other raw materials will be changed; Using corn stalk as raw material and add auxiliary materials which made from a variety of materials, through crosslinking foaming forming, and then through the drying, disinfection and other processes, can be made into a one-time full degradation foam tableware [14]; Taking straw as a building material application, it is used for furniture production, because it has the characteristics of high strength, light weight and low price, it can replace part of the wood board and reduce the pressure of forest ecosystem in the process of social development [15].

"One two five" period, China actively promote scientific utilization of straw pulping and papermaking, the positive development of straw board production and production process, pilot construction of straw to produce xylitol, straw activated carbon and other emerging engineering, and constantly improve the industrialization of straw utilization level.

\section{Corn straw fuel utilization.}

As a kind of important biomass energy, the energy of 2 tons of corn straw can be replaced by the energy of the corn stalk. Promotion of straw energy utilization can effectively reduce the energy consumption. "One two five" period, China has great efforts to develop straw biogas, straw curing type fuel, direct fired power generation, straw carbonization, etc ,in order to improve the proportion of renewable energy structure.

The biogas is a high-quality renewable energy, is the way to change the traditional way to get the fuel, the development of clean energy and the protection of the environment ideal measures. The use of straw anaerobic fermentation to produce biogas, can be used in the condition of smaller scale and less capital investment to achieve efficient utilization of biomass resources, and which is more suitable for rural and town and country enterprises in developing countries and regions.

The straw curing molding fuel is a form of the crop under the effect of certain temperature and pressure. General straw compression molding after 10 times the size of the left, easy to store and transport, energy density is also greatly enhanced, equivalent to the coal density. Combustion performance has been significantly improved, can replace wood and coal to provide a living food or heating purposes for rural residents, can also replace natural gas, fuel .So it is a new economic and practical fuel. 


\section{Corn straw carbon comprehensive utilization.}

Straw carbonization refers to the process of crop straw transform pyrolysis to biological carbon in anaerobic conditions. The corn straw can be used directly in the power plant to generate electricity, while the biological carbon is the corn straw in the condition of not fully burning.

As the global changing situation is getting more and more serious, the demand for climate change is increasingly strong. The agricultural biomass waste carbonization technology has become a new way of increasing carbon sequestration and reducing waste and greenhouse gas emissions.

In recent years, biological carbon as soil conditioner, fertilizer release carrier and carbon sequestration agent has been paid much attention [16]. From the point of view of improving soil fertility, corn straw carbon is rich in organic carbon, can increase the soil organic carbon content, soil organic matter or humus content [17], and improve the soil nutrient uptake capacity and water holding capacity [18]. At the same time, with good physical properties and nutrient regulation, the application of soil can significantly promote the seed germination and growth, so as to promote crop productivity.

Biological carbon has high adsorption capacity, CEC and chemical reaction, therefore, biological carbon can be used as a carrier of slow release fertilizer, slow release of nutrients in the soil and reduce the loss of fertilizer nutrient leaching and fixation, improved fertilizer utilization rate of $[19,20]$. Because of the rich micro pore structure and specific surface area, Biological carbon is the application of soil ,one hand the soil bulk density can be reduced, and the soil structure and water, fertilizer, gas and heat can be improved. On the other hand it can provide shelter for soil microorganism, promote microbial communities to thrive [21,22].

Biological carbon has rich stable carbon, mainly composed of aromatic hydrocarbons and elemental carbon or carbon graphite like structure, has physical and chemical properties of stability and high anti biodegradation ability[23]. This makes the biological carbon has a "carbon sequestration" function, Change the crop straw and other agricultural and forestry wastes to biological carbon to replace the incineration, can effectively reduce greenhouse gas emissions and increase” the agricultural carbon sink".

Biological carbon has a remarkable effect on carbon sequestration, Soil improvement and fertilizer efficiency, Along with the development of carbon products, it is found that it has a good application prospect in the field of environmental protection. Use waste biomass pyrolysis to produce bio carbon ,not only to obtain bio oil and mixed gas , and can be further upgraded to hydrogen and chemicals, to increase the added value of waste biomass, which can promote the use of waste biomass, to achieve the effective management of waste[24].

\section{The utilization of corn straw in foreign countries.}

According to research, more than $70 \%$ of the developed countries are basically used for field. In Canada ,In october corn has been riped, corn harvester chopped corn straw as fertilizer to the field while the corn stalk chopped; The use of straw in the United States is very wide, it can be used as feed, handmade products, etc. The recent emerging straw ethanol has been strongly supported by the federal government. The United States currently has 116 ethanol extract manufacturers, and can produce 5900000000 gallons of ethanol per year; Denmark is the world's first use of straw power generation countries .After farmers harvest food, the straw are sold to power plants .Compared with coal, oil, natural gas, straw has the low cost, less pollution, straw burning ash can be returned to farmers as fertilizer.

\section{Summary}

In the traditional planting process, corn straw is a valuable production and living resources for the farmers. And for the use of straw, the first is the field. The straw itself comes from the land, the straw can effectively increase the soil organic matter, improve soil aggregate structure and physicochemical properties. It is understood that in most of the developed countries,corn straw are used for field. Such as, for the United States annual production of 4.5 tons of crop stalks, straw returning is amount of $68 \%$. But according to our country's resources and environment, compared with only used as the energy of life and feed in the past, we have explored a variety of forms of corn 
straw utilization, which has been used in the field of "five materials" , And also gradually formed a breeding - biogas fermentation - planting - power and other agricultural and animal husbandry and animal husbandry combined with the ecological cycle of agriculture, the use of industrial thinking and way to do agriculture, improve the utilization of straw , and also opened up new space for straw comprehensive utilization.

\section{References}

[1]. Jingchang Wang ,et al. The present situation and development strategy of comprehensive utilization of corn straw[J]. Agricultural science and technology communication, 2012, (11) :95-98.

[2]. Zhonglan Gao, et al. Advantage and technology of corn straw returning to field[J]. Modern agricultural science and technology, 2013,(1):226-227.

[3]. Yunling Zhao, et al. The crop straw form and application mode[J]. The grass-roots agricultural technology extension,2015,(8):70-73.

[4]. Xiangpeng Wang ,et al. Analysis on the treatment and comprehensive utilization of agricultural crops in the[J] . Agricultural Sciences,2015,(7):82-83.

[5]. Yang Sun ,et al. Discussion on the technology of straw returning to field and[J] . in southern China, 2015, (7): 155-156.

[6]. Jinling Pan ,et al. Effect and mechanism of straw returning on soil organic matter and nitrogen availability and mechanism of soil organic matter and nitrogen in China[J] . Chinese Journal of ecology and agriculture, 2013,21 (5): 520-535.

[7]. Zhonglan Gao ,et al. Advantage of corn stalk returning to field and its technology [J]. modern agricultural science and technology, 2013, (1): 226-227.

[8]. Jiangao Qi,et al.Several ways of the comprehensive utilization of straw[J]. three agricultural and rural Lun Tan, 2014,31 (10): 11-12.

[9]. Dongwei Zhang,et al.The present situation and Prospect of the utilization of silage corn[J]. Ecology and environment, 2011, (10): 94-95.

[10]. Xiaofu Liu,et al.Biological characteristics and utilization of crop straw[J]. agricultural services, 2014,31 (10): 99-100.

[11]. Tao Xie,et al. The application of [J]. technology and agricultural situation and Nang corn straw pellet feed corn straw feed, 2010,30 (1): 66-68.

[12]. Xiuhong Hua , et al. The application of [J] in agricultural straw mushroom production. Ecology and environment, 2010,26 (4): 390-393.

[13]. Shuyi Wang,et al. Development trend of comprehensive utilization of corn straw [J]. Jilin animal husbandry and veterinary medicine, 2004, (1): 26-27.

[14]. Chunhua Ban,et al. Current situation and development trend of the application of corn straw [J] agricultural science and technology and equipment, 2014, (12): 61-62.

[15]. Xusheng He ,et al. Biological carbon production and agricultural significance [J]. Journal of agricultural engineering, 2011 (2): 1-7.

[16]. Lehmann J, Gaunt J, Rondon M. Bio-char sequestration inter restrial ecosystems-a review[J]. Mitigation and Adaptation Strategies for Global Change, 2006, 11: 403-427.

[17]. Steiner C, Glaser B, Teixeira W G, et al. Nitrogen retention and plant uptake on a highly weathered central Amazonian Ferrasol amended with compost and charcoal[J]. J Plant NutrSoil Sci, 2008, 171(6): 893-899. 
[18]. Magrini-Bair K A, Czernik S, et al. Biomass derived, carbon sequestering, designed fertilizers[J]. Annals of Environmental Science,2009, 3(December)

$[19,20]$. Steinbeiss S, Gleixner G, Antonietti M. Effect of biocharamendment on soil carbon balance and soil microbial activity . Soil Biology \& Biochemistry, 2009, 41(6): 1301-1310.

$[21,22]$. Yoshizawa S, Tanaka S. Acceleration of composting of food garbage and livestock waste by addition of biomass charcoal powder[R]. Asian Environmental Research, 2008, 1: 45 50.(http://acer.meisei-u.ac.jp.r)

[23]. Laird D A, Brown R C, Amonette J E, et al. Review of the pyrolysis platform for coproducing bio-oil and biochar[J].Biofuels, Bioproducts and Biorefining, 2009, 3(5): 547-562.

[24]. Brewer C E, Schmidt-Rohr K, J A Satrio, et al. Characterization of biochar from fast pyrolysis and gasification systems[J].Environmental Progress and Sustainable Energy, 2009, 28(3): 386396. 